\title{
In Antalya: The Factors Causing People to Go to the Village Café, the Place of Origin Café and the Cafés of the City Center
}

\author{
Bireylerin Köy Kahvesi, Memleket Kahvesi ve Şehir Merkezindeki Kafelere \\ Gitme Nedenlerini Etkileyen Faktörler: Antalya Örneği
}

Faik ARDAHAN*

\begin{abstract}
The purpose of this research was to determine the reasons leading individuals to visit the Village Cafés (VCS), City Center Cafés (CCC) and Place of Origin Cafés (CCS). There were in total 300 participants in three group each of 100 participants. The questionaire form was of two parts, firstly the demographic variables and secondly concerning the reasons which caused participants to go to these localities. In assessing this data both descriptive statistic methods and the One-way ANOVA test were employed, and the results assessed according to a 0.05 level of significance. A five-point Likert scale was used, the range, " $l=$ strongly disagree" to " $5=$ strongly agree". As a result of this study, it can be concluded participants living in the city have the possibility to go to cafés have a recreational advantage, and they spend more money and much more time on their recreational life than the other participants. The participants prefer inactive leisure activities like watching TV, resting at home and family togetherness; the reasons for going to cafés were friend-focused, being with friends, eating/drinking/playing something with them. But in the village there was a lack of recreational alternatives and the men have to go the VCS, and they prefer inactive leisure.
\end{abstract}

Keywords: Village Café, Place of Origin Café, City Center Cafés, Recreation, Antalya

$\ddot{O}_{z:}$ Bu çalışmanın amacı bireylerin Köy Kahvesi, Memleket Kahvesi ve Şehir Merkezindeki Kafelere Gitme Nedenlerini belirlenmesidir. Örneklem gurubu üç farklı grubun herbirinden 100 katılımcı olmak üzere toplam 300 kişiden oluşmaktadır. Anket formu iki bölümden oluşmaktadır. Birinci bölüm; demografik bilgilerin alındığı sorlardan, ikinci bölüm; bireyleri bu mekanlara gitmeye motive eden faktörlerin belirlendiği maddelerden oluşmuştur. Verilerin analizinde tanımlayıcı istatistiklerin yanında, karşılaştırmalarda ANOVA testi kullanılmış ve sonuçlar 0.01 ve 0.05 anlamlılık düzeyinde sorgulanmıştır. Çalışmada beşli Likert ölçeği (1- Kesinlikle Katılmıyorum,..., 5- Kesinlikle Katılıyorum) kullanılmıştır. Sonuç olarak şehirde yaşayanlar ve şehir merkezindeki kafelere gitme firsatı olan bireyler diğer katılımcılara göre daha fazla rekreasyonel avantaja sahipler, rekreasyonel gerekçelerle daha fazla para ve zaman harcamaktadırlar. Katılımcılar TV izlemek, evde dinlenmek, aile ile vakit geçirmek gibi daha çok pasif rekreasyonel aktiviteleri tercih etmektedirler, kafelere gitme nedenleri arkadaşlarıyla birlikte olmak, beraber bir şeyler yemek, içmek ve oynamak gibi arkadaş odaklıdır. Bunun yanında; köylerde rekreasyonel alternatiflerin azlı̆̆ı/yokluğu erkek bireyleri köy kahvesine gitmeye ve pasif rekreasyona zorlamaktadır.

Anahtar sözcükler: Köy Kahvesi, Memleket Kahvesi, Şehir Merkezindeki Kafeler, Rekreasyon, Antalya

\footnotetext{
* Assoc. Prof. Dr., Akdeniz University, School of Physical Education and Sport, Recreation Department, Antalya/Turkey. ardahan@akdeniz.edu.tr
} 


\section{Introduction and Review of the Literature}

Public and place are co-joined for all societies over the course of history. As had been the case throughout the history of Anatolia, in the Ottoman period, public dynamics created their own culture and communal places which fed, managed, and supervised communal and recreational activities, politics, and social rituals. Individuals and society have needed defined places indoors or outside to interact and associate together from the dawn of history (Sankır 2010; Aktaş 2011).

In Anatolia, within Ottoman culture, the number of communal places where individuals come together to celebrate or to memorialize in ceremony was limited and by the public's rules they were separate for men and women. Men and women were also separated within large families except for the nuclear family. The communal places were the mosques, cafés, popular excursion areas, bazaars and markets, and the public baths in Anatolia and in Ottoman (Evren 1996; Y1ldız1996; Sankır 2010; Aktaş 2011).

Mosques are one of the most important communal places where Muslim members of the community together for group and individual prayers and socialization. Men who are resident in the same neighborhood usually come together five times (dawn prayer, dhuhr prayer, afternoon prayer, sunset prayer, and night prayer) during the course of a day in mosques to talk about current issues and social subjects. It was not permitted for men and women to come together for any reason in mosques, but during the last three decades, the social rules have changed so that men and women come together in separated areas with mosques at funeral ceremonies, and in some Islamic memorial services such as for tarawih prayer (Yıldız 1996; Shirine 2007; Aktaş 2011). However, from the establishment of the Turkish Republic in 1923, Turkey has been a secular country and life for men and women is similar to that in European contries.

Local and regional bazaars and markets were the most important public places in Anatolian social life Özünlü 2010). All these places played an important role in Ottoman urban structuring and different bazaars were established and markets for different needs on different days of the week in the neighborhoods within the cities, which enrich urban social life. The bazaars and markets were used mainly by women, especially on Friday while men were at Friday prayers. The importance of markets is still continues in the urban life of the cities, towns and villages. But the markets and bazaars were places of only limited possibilities for organized social relationships (Öztürk 2005; Aktaş 2011).

Popular excursion places and picnic areas where women and children came together were important social interaction domains where individuals came together although having different socio-demographic characteristics, such as different ethic origin, social status and age. Popular excursion places, picnic areas, early-bird cafés, coffee houses and drinking houses are within the men hegemony (Hamadeh 2007; Aktaş 2011).

The public or Turkish Bath was an important communal place where women met and socialized with other women and the meaning and importance of the Turkish Bath still continues today. It has separate sections or different time schedule for bathing for the men and the women. Women meet there for many reasons, for talking, eating, celebrating a wedding or an engagement etc. (Yıldız 1996; Aktaş 2011)

The café in Ottoman culture was the place which served only coffee. The first café was opened in Mecca and Cairo in about 1511 and then a café was opened in İstanbul in 1553 and visiting a café rapidly become popular (Ediz 2008; Aktaş 2011). In the beginning, coffee was the official drink of the Ottoman Palace and was a special drink for members of the Ottoman upper class, but later, coffee began to be serve in cafés to middle and low class people all around the cities, towns and villages in places which were termed "Kahvehane" in Turkish and these locations then obtained their important roles within communal life. When these places 
became popular and became a common place of Ottoman communal life, they began to be perceived as places where social togetherness and recreational opportunities were created. Cafés were places which were frequented only by men, for meeting, talking about the days' topics of converstion, for socialization and a place to spend their free time without any communal limitation. In some cafés there were laudatory poets, epic poets and the presentation of shadow theatre plays and improvisations of Hacivat and Karagöz enriching the social life of the neighborhood (Duben 2001; Aktaş 2011).

Drinking alcohol is not allowed for Muslims, wrong under Islamic law. For this reason the drinking houses throughout Ottoman territory were open for the non-Muslim population. The recreational use of cafés was accepted as being the same as the drinking houses for Muslims during daylight hours or in night (Hattox 1998). Coffee was the drink which increases alertness without causing drunkeness. Muslims drank it in all through the day and especially before they prayed (Durukan 2013)

In Anatolia in Ottoman culture, the gathering together of women and their socialization was permitted only in the home/indoor facilities with their children and other women, not out of the home and not together with men who were either acquaintances or strangers. Outside the home, cafés were the one of the most important places where men came together. Last few decades, women were allowed to go to coffee house and drinking houses with men or alone (Hattox 1998; Heise 2001; Bingül 2004; Öztürk 2005; Aktaş 2011; Durukan 2013).

Publications for Ottomans such as books, magazines and newsletters were limited in quantity and some cafés make them available for reading, as in a library, and at the same time served coffee and tea to their customers. This type of establishment began to be called coffee houses (Kıraathane in Turkish) and the first opened in Beyazit in İstanbul in the middle of the $19^{\text {th }}$ century. It was believed that these coffee houses were adopted from the example of European Culture Clubs (Evren 1996).

Cafés and coffee houses became prevalent and had an important role in the daily social and cultural life of Anatolia for the Ottomans from the beginning of the $16^{\text {th }}$ century. These places were communal centers and places which enabled social opportunities to occur in neighborhoods in addition to civil and religious places. Their importance, their business design and recreational specialties still remain similar and continue within the present social life of cities, in towns and in villages in all around Turkey (Tokman 2001; Ayalp 2007; Aktaş 2011; Ulusoy 2011; Durukan 2013). Coffee with Male hegemony continues in cafés and coffee houses.

There were different types of cafés/coffee houses due to the functional use of cafés, and social strata, demographic differences between individuals and their expectations from particular cafés. There were neighbourhood cafés, artisan cafés, janissary cafés, semai (tavern) cafés, cultivation cafés, hashish addict cafés, addict cafés, laudatory cafés, mobile cafés, stargazer cafés, fisherman cafés, dancing boys cafés, wrestler cafés, treasure hunter cafés, labourer cafés, early riser cafés, tea house cafés and hookah cafés (Evren 1996; Yıldız 1996; Yağbasan \& Ustakara 2008; Aktaş 2011). All of these different café types change heterogenic communal demands into homogeneity. Today some types of cafés are no longer to be found, such as the janissary cafés, hashish addict cafés, addict cafés, dancing boys cafés, wrestler cafés, laudatory cafés and mobile cafés which have all faded away. In addition to these, the migration from village to urban or from some disadvantaged cities to advantaged cities have created the Place of Origin cafés in urban settlements.

The Place of Origin cafés (CCS) are usually of a small size and is a private business or belongs to a local of association related to the original locality of the migrants, and it is usually possible to find there some sandwiches, toasted sandwich and/or some appetizer for eating and some tea, coffee or some alcohol free drinks except beer for drinking, and the necessary for 
some games such as: backgammon, dominos, card games and a television for collectively watching some events. The CCS where only men come together, were established to support individuals who come from the same place of origin (the same village, town, cities) for socialization, for finding a job, or for finding accommodation etc.

Villages are the smallest settlement unit and usually any village will have one or two cafés to enable the men of the village to associate. The Village Cafés (VCS) are usually of a small size and run as a private business and it is usually possible to find there some sandwiches, toasted sandwiches and/or some appetizer for eating and some tea, coffee or some alcohol free drinks except beer for drinking and the necessary for playing games such as backgammon, dominos, card games and a television for watching events on the TV. Of course villages are small and communal pressure is the main determinant of many social structures and of social life. Men are expected and forced to have a social life outside their home with only male friends. If a man wants to stay at home with his family, his close friends call him a "henpecked husband - Kllıblk in Turkish" (Tezcan 1994; Yıldız 1996).

In Turkey, usually women cannot find opportunity (or their families/husbands/adults do not give them permission) to go to (or to spend time in) VCS and CCS. This can be understood as peer pressure upon females. These two localities can be accepted as male preserves.

City center cafés (CCC) are, just like VCS and CCS, usually of a small size and are a private business and it is usually possible to find there some sandwiches, toasted sandwiches and/or some appetizer to eat, and some tea, coffee or some alcohol free drinks except beer for drinking and the necessary for playing some games such as billiards, table tennis, backgammon, dominos, card games and for watching some events on TV.

The reasons creating wellness and/or well-being are used to explain the reason for any recreational behaviour which has drawn the attention of researchers over the last four decades. While Crandall (1980) claimed that the conditions in which an individual lives and personality motivate people to do something, Levy (1979) concluded that behaviour is the result of the interaction between social relations/conditions and personality. In addition to these, İbrahim and Cordes (2002) concluded the reasons with Maslow's hierarchy of needs. Furthermore, Deci and Ryan (1985) claimed to show the reason for behavior with the Self-Determination Theory, Pintrich (2000); claimed the reason for behavior with the Achievement Goal Theory, while Engeström et al. (2003) claimed the reason of behavior with the Activity Theory. Going to the CCC, the VCS, and the CCS can be accepted as a recreational behavior/activity which creates physical, emotional and/or mental happiness and the reason or the reasons can be explained by the motivation theories that are listed above.

Despite their recreational and social benefits, cafés/coffee houses whether in the village or in the city carry some positive and negative functions or effects. The positive functions of cafés are a) individuals are able to have face to face conversations in these places, b) these places provide opportunities for socialization, communications, for idle talk, for watching TV, reading something, and to play some games (Tezcan 1994; Yildız 1996). In addition to these some further reasons can be added; c) men from all age groups come together, d) these places are sometimes the main recreational places within the cafe's neighbourhood, e) these places are usually the places for communal problem solving and the decision making areas, $f$ ) these places have their own boards of alderman for communal consultancy. The negative functions of cafés are (Atay 1985; Tezcan 1994; Y1ldız 1996). a) it affects men negatively, by distracting them from work/working and draws the frequenter towards laziness, b) these places prevent to novelnew skills and specialization in any subject except for games, c) these places can be effective in forming groups of individuals who are of the same political view, of the same ethnic origin, from the same hometown/country and/or of the same sect, strengthening the forces of possible 
communal conflict, d) because groups of the same political view, the same ethnic origin, the same hometown/country and the same sect serve to prevent the formation of community unity, e) the cafés, coffee houses, and CCS can prevent and/or slow the integration of individuals within the cities/urban landscape and with other individuals living in same neighborhood, $f$ ) there can be hygiene problems in these places, g) these places can provide a bad example for the youth gaining the habit of frequenting them, h) the increasing ability of an individual in playing some games can result in addiction to gambling, i) these places bring any kind of people together and may be effective to create new friendships which might lead both or one side of this relations withholding their attention from their own home and family, j) time wasting and spending some money in these places can cited as a reason for family conflict between husband and wife or between a boy and adults.

There is little research concerning the sociological importance of cafés and coffee shops in Turkish sociological literature.

- Atay (1985) studied the the urbanization problems of individuals who immigrate to 1800 Evler Street in Elazig due to the construction and filling of the Keban Dam. He asked the immigrants how they spent their free time and the participants' preference was to meet with friend and neighbors and talk about daily life in the coffee house.

- Tezcan (1994) wrote a book on the sociology of leisure.

- Yildiz (1996) studied the importance of cafés in social life.

- Shirine (2007) studied İstanbul's community life in XVIII century and how important were coffee shops within this communities' life.

- Yağbasan \& Ustakara (2008) studied the communicative atmosphere within the coffee houses and cafés of Turkish society.

- Sankır (2010) studied the role and importance of coffee houses in social life in Ottoman Empire.

- Ulusoy (2011) made a verbal culture and environmental education study of coffee and coffee house culture within Turkish society.

The main difference of this study from the others above is in examining the reasons defining the recreational importance of the VCS, CCS and CCC.

\section{Methodology}

The purpose of this research was to determine the reasons leading individuals to visit VCS, $\mathrm{CCC}$ and CCS.

Sampling: There were a total of 300 participants in three groups, each with 100 participants. First group were living in the villages and going to the VCS, the second group were living in the city center and going to the CCS and the third group of participants were living in the city center and going to the CCC in Antalya.

The participants ( $\overline{\mathrm{X}}$ age $37,99 \pm 14,30$ ) who live/work/have settled in the village were $\% 100$ male. There are 537 villages in Antalya and six villages and the 100 participants were selected from them employing the simple random sampling method. Three of were about 20-30 km from the city center of Antalya (Aksu, Döşemealtı and Duac1) and the rest were about 80-100 km from the city center of Antalya (Kızılağaç, Doğançam and Karacalar villages in the Manavgat district).

There are many (the actual number is unknown) CCS in the Antalya city center. Seven of these and the participants were selected using the simple random sampling method. The participants come from Malatya, Erzincan, Ankara, Gazipaşa, Muş, Kağızman, Ağrı and all they ( $\bar{X}$ age $49,32 \pm 11,11$ ) were permanently and/or temporarily living in the Antalya city center and were $\% 99$ male. 
There are hundreds of CCC in Antalya city center. Three famous cafés, the Uğur CaféBilliard Saloon, the Kristal Café, and the Platin Café, and the participants were selected using the simple random sampling method. The CCC participants were in total 100 persons $(\overline{\mathrm{X}}$ age $29,92 \pm 10,99) 61 \%$ male and $39 \%$ female.

The Tool of Gathering Data: The questionaire form included two parts, first the demographic variables, secondly the factors that influenced respondents to go these localities. In the process of assessing data the descriptive statistic methods, One-way ANOVA test and Tukey test were employed and the results assessed according to a significant level of 0.05. A five-point Likert scale was used and the range covered " $1=$ strongly disagree" to " $5=$ strongly agree".

\section{Results}

Demographic information concerning the participants is given in Table-1. As recorded, the majority of participants were aged between 20-50 years (65.3\%), male (86.7\%), married (63.3\%), had monthly income between 321-1280\$ (74,0\%), well educated (High school or above) $(63.7 \%)$, were employed $(62.3 \%)$, going to the café/coffee house at the weekend. Unfortunately, sampling didn't include equal proportions of female and male individuals. Females do not have the chance to go to the VCS and CCS, because of peer pressure on females. Their families/husbands/parents do not give them permission to spend time in the VCS and CCS. It can be said that these localities can be accepted as areas governed by males.

Table 1. Demographic variables of participants

\begin{tabular}{lcc}
\hline Variables & n & \% \\
\hline The Participants of VCS & 100 & 33.3 \\
The Participants of CCC & 100 & 33.3 \\
The Participants of CCS & 100 & 33.3 \\
\hline 19 years old and below & 22 & 7.3 \\
20-30 years old & 86 & 28.7 \\
31-40 years old & 52 & 17.3 \\
41-50 years old & 58 & 19.3 \\
51 years old and upper & 82 & 27.3 \\
320 \$ and below & 62 & 20.7 \\
\hline 321-640\$ & 126 & 42.0 \\
641-1280\$ & 96 & 32.0 \\
1281\$ and more & 16 & 5.3 \\
Primary school & 109 & 36.3 \\
\hline High school/Vocational high-school & 91 & 30.3 \\
Bachelor and upper & 100 & 33.4 \\
The Participants of VCS & 100 & 33.3 \\
\hline
\end{tabular}

\begin{tabular}{lcc}
\hline Variables & n & $\mathbf{\%}$ \\
\hline Male & 260 & 86.7 \\
Female & 40 & 13.3 \\
\hline Married & 190 & 63.3 \\
Single & 110 & 36.7 \\
\hline Public Sector & 30 & 10.0 \\
Retired & 45 & 15.0 \\
Housewife & 4 & 1.3 \\
Own work & 60 & 20.0 \\
Private Sector & 51 & 17.0 \\
Students & 44 & 14.7 \\
Unemployed & 23 & 7.7 \\
Self-employment & 43 & 14.3 \\
\hline Total & $\mathbf{1 0 0}$ & $\mathbf{1 0 0 . 0}$ \\
\hline Going to the Coffee house in & 230 & 76.7 \\
weekdays & & \\
Going to the Coffee house at & 289 & 96.3 \\
the weekend & & \\
\hline & &
\end{tabular}

$* 2.35 \mathrm{TL}=1 \$$ on the $05 / 1 / 2015$

In the majority of the villages of Turkey, men and woman usually use separate areas in their leisure activities, excluding some parts of Turkey, where the religion is alevism and for some people who have different paradigm from the majority. This is influenced by religion, manners and customs, the paradigm of the individual and by society.

The amount of weekly wasted time (time spent) and money in café/coffee shop are given in Table-2. As seen in Table-2, the average age of CCC participants was younger than the others, 
each person whether in the village or in the city center spends an average of $22 \$$ per week (about $8-10 \%$ of monthly income) in café/coffee shop. Even if they went to the café/coffee shop on weekdays more than weekends, they spent an average of 12 hours in the week, more than the time spent at weekends (which is about an average of 8.1 hours a week). There was a statistically meaningful difference in time spent-wasted in the café/coffee shop at weekend and on weekdays. This means that the participants living in the village and the participants going to the CCS spent more than the CCC's participants. When comparing the time and the amount of money spent, the CCC participants spend less time in the café, but spend more money than the others. It can be concluded that the cafés in the city are more expensive than the VCS and CCS.

Table 2. Wasted time (time spent) by participants in café/coffee shop and comparison by café types

\begin{tabular}{|c|c|c|c|c|c|}
\hline $\begin{array}{l}\text { Wasted time of Participants in } \\
\text { Café/Coffee Shop }\end{array}$ & $\begin{array}{c}\text { Total } \\
\text { Results } \\
\text { Mean } \pm \text { SD }\end{array}$ & $\begin{array}{c}\text { VCS } \\
\operatorname{Mean} \pm \text { SD }\end{array}$ & $\begin{array}{c}\text { CCC } \\
\operatorname{Mean} \pm S D\end{array}$ & $\begin{array}{c}\text { CCS } \\
\text { Mean } \pm \text { SD }\end{array}$ & $\mathbf{F}$ \\
\hline Average age & $39.08 \pm 14.56$ & $37.99 \pm 14.30$ & $29.92 \pm 10.99$ & $49.32 \pm 11.11$ & --------- \\
\hline $\begin{array}{l}\text { Money spent in Café/Coffee shop in a } \\
\text { week (\$) }\end{array}$ & $22.37 \pm 29.46$ & $21.89 \pm 42.47$ & $22.83 \pm 22.74$ & $22.38 \pm 17.29$ & 0.025 \\
\hline $\begin{array}{l}\text { Total time spent-wasted in } \\
\text { Café/Coffee Shop on weekdays } \\
\text { (hours) }\end{array}$ & $11.51 \pm 8.89$ & $15.99 \pm 8.10$ & $6.45 \pm 6.43$ & $12.09 \pm 9.25$ & $11.035^{*}$ \\
\hline $\begin{array}{l}\text { Total time spent-wasted in } \\
\text { Café/Coffee Shop at the weekend } \\
\text { (hours) }\end{array}$ & $8.10 \pm 5.20$ & $8.69 \pm 4.94$ & $6.04 \pm 5.15$ & $9.56 \pm 4.89$ & $4.680 *$ \\
\hline $\begin{array}{l}\text { How many weeks ago did you read a } \\
\text { book? }\end{array}$ & $3.76 \pm 15.79$ & $3.38 \pm 21.03$ & $5.16 \pm 16.49$ & $2.74 \pm 6.04$ & 1.143 \\
\hline $\begin{array}{l}\text { How many weeks ago did you go to } \\
\text { cinema? }\end{array}$ & $5.03 \pm 12.71$ & $3.99 \pm 15.72$ & $5.09 \pm 9.89$ & $6.00 \pm 11.87$ & 0.520 \\
\hline $\begin{array}{l}\text { Time spent watching TV per week } \\
\text { (hours) }\end{array}$ & $20.77 \pm 15.55$ & $26.89 \pm 13.15$ & $11.66 \pm 15.68$ & $23.75 \pm 13.45$ & 7.354* \\
\hline
\end{tabular}

It can be concluded that none of the participants read books or go to cinemas either regularly or frequently. Even if there was no statistically meaningful difference, among the participant groups, the VCS participants and CCS participants spent more time reading a book than CCC participants. It can be said that, each month all of the participants read/finish a book.

There was no statistically meaningful difference among the participant groups about going to the cinema. The average frequency for going to cinema was once every 5 weeks. The participants did not prefer going to cinema more often.

The participants spend their leisure time watching TV. The average time spent watching TV was about 21 hours a week. There was a statistically meaningful difference among the participant groups. The VCS and CCS participants spent more time watching TV than the city center café participants. This could be due to a lack of alternative leisure activities or some different leisure constraints which were not addressed in the questionnaire form. When the reasons were listed in Table-4, one of the major reasons given by the VCS participants was the lack of alternative leisure activities and places. But the reasons were not clear for the other participants.

The leisure activities of participants except for sport are given in Table-3. As given in the table, all the participants were willing to participate in passive recreational activities such as watching TV (81\%), resting at home $(79.3 \%)$, family togetherness $(71 \%)$, going shopping and window shopping in a mall $(52.7 \%)$. VCS and CCS participants spent much more time 
watching TV, resting at home, in family togetherness, going for shopping and window shopping than the CCC participants. But in contrast, the CCC participants spent much more time surfing in internet, wasting-spending time in social media and in active recreational activities like going to the cinema, going to the theatre, being interested in photography, being interested in music and being interested in handicrafts than the other two groups of participants. This could be the result of differences in education level (participant from city center are advantaged, as their education level was higher than the others), in recreation culture and different expectations "while the VCS and CCS participants were willing to spend their leisure time for passive leisure activities, the CCC participants were willing to spend their leisure time for active leisure activities) or marital status (while the VCS (66.0\%) and CCS participants (\%88.0) were mainly married, the CCC participants were mainly (64.0\%) single".

Tablo 3. Leisure time activities except for sports

\begin{tabular}{|c|c|c|c|c|c|c|c|c|}
\hline \multirow[t]{2}{*}{ Activities Except for Sports } & \multicolumn{2}{|c|}{$\begin{array}{c}\text { Total } \\
\text { Results }\end{array}$} & \multicolumn{2}{|c|}{ VCS } & \multicolumn{2}{|c|}{$\mathrm{CCC}$} & \multicolumn{2}{|c|}{ CCS } \\
\hline & $\mathbf{n}$ & $\%$ & $\mathbf{n}$ & $\%$ & $\mathbf{n}$ & $\%$ & $\mathbf{n}$ & $\%$ \\
\hline Watching TV & 243 & $\begin{array}{c}81.0 \\
100.0\end{array}$ & 96 & $\begin{array}{l}96.0 \\
39.5\end{array}$ & 54 & $\begin{array}{l}54.0 \\
22.2\end{array}$ & 93 & $\begin{array}{l}93.0 \\
38.3\end{array}$ \\
\hline Resting at home & 238 & $\begin{array}{c}79.3 \\
100.0\end{array}$ & 87 & $\begin{array}{l}87.0 \\
36.6\end{array}$ & 67 & $\begin{array}{l}67.0 \\
28.2\end{array}$ & 84 & $\begin{array}{l}84.0 \\
35.3\end{array}$ \\
\hline Family Togetherness & 213 & $\begin{array}{c}71.0 \\
100.0\end{array}$ & 76 & $\begin{array}{l}76.0 \\
35.7\end{array}$ & 52 & $\begin{array}{l}52.0 \\
24.4\end{array}$ & 85 & $\begin{array}{l}85.0 \\
39.9\end{array}$ \\
\hline $\begin{array}{l}\text { Going shopping and } \\
\text { Window shopping in a shopping mall }\end{array}$ & 158 & $\begin{array}{c}52.7 \\
100.0\end{array}$ & 48 & $\begin{array}{l}48.0 \\
30.4\end{array}$ & 45 & $\begin{array}{l}45.0 \\
28.5\end{array}$ & 65 & $\begin{array}{l}65.0 \\
41.1\end{array}$ \\
\hline Surfing the internet & 140 & $\begin{array}{c}46.7 \\
100.0\end{array}$ & 34 & $\begin{array}{l}34.0 \\
24.3\end{array}$ & 61 & $\begin{array}{l}61.0 \\
43.6\end{array}$ & 45 & $\begin{array}{l}45.0 \\
32.1\end{array}$ \\
\hline Going to the cinema & 131 & $\begin{array}{c}43.7 \\
100.0\end{array}$ & 23 & $\begin{array}{l}23.0 \\
17.6\end{array}$ & 58 & $\begin{array}{l}58.0 \\
44.3\end{array}$ & 50 & $\begin{array}{l}50.0 \\
38.1\end{array}$ \\
\hline Spending time on social media & 58 & $\begin{array}{c}19.3 \\
100.0\end{array}$ & 10 & $\begin{array}{l}10.0 \\
17.2\end{array}$ & 29 & $\begin{array}{l}29.0 \\
50.0\end{array}$ & 19 & $\begin{array}{l}19.0 \\
32.8\end{array}$ \\
\hline Going to the theatre & 46 & $\begin{array}{c}13.0 \\
100.0\end{array}$ & 7 & $\begin{array}{c}7.0 \\
15.2\end{array}$ & 25 & $\begin{array}{l}25.0 \\
54.4\end{array}$ & 14 & $\begin{array}{l}14.0 \\
30.4\end{array}$ \\
\hline Being interested in photography & 34 & $\begin{array}{c}11.3 \\
100.0\end{array}$ & 6 & $\begin{array}{c}6.0 \\
17.6\end{array}$ & 18 & $\begin{array}{l}18.0 \\
52.9\end{array}$ & 10 & $\begin{array}{l}10.0 \\
29.5\end{array}$ \\
\hline Being interested in music & 31 & $\begin{array}{c}10.3 \\
100.0\end{array}$ & 6 & $\begin{array}{c}6.0 \\
19.4\end{array}$ & 21 & $\begin{array}{l}21.0 \\
67.7\end{array}$ & 4 & $\begin{array}{c}4.0 \\
12.9\end{array}$ \\
\hline Being interested in handicrafts & 25 & $\begin{array}{c}8.3 \\
100.0\end{array}$ & 11 & $\begin{array}{l}11.0 \\
44.0\end{array}$ & 12 & $\begin{array}{l}12.0 \\
48.0\end{array}$ & 2 & $\begin{array}{l}2.0 \\
8.0\end{array}$ \\
\hline
\end{tabular}

Leisure sports activities are given in Table-4. As recorded in the table, 27\% of the participants were mostly willing to participate in outdoor sports like mountaineering, rock climbing, and trekking, fishing, hunting, team sports like football, basketball, and volleyball, water sports like swimming, sailing, and canoeing. All other recreational sports were not preferred as much by participants. In addition, when sport activities are compared with other recreational activities except for sport, all participants were willing to participate in passive activities. Furthermore, fitness, leisure sport activities done in urban parks, folk dance and modern dance, individual sports, air sports, rackets sports, and motor sport were mostly preferred by CCC participants. Because the CCC participants have the opportunity to do these sports and, when compared, their income and educational level was higher and their life paradigm was more positive than the other two groups of participants. Martial Arts, like wrestling, karate, taekwondo are preferred mostly by VCS participants in particular, because oil wrestling is common in neighborhoods of Antalya and some famous wrestlers have come from Antalya. 
Table 4. Sportive leisure activities

\begin{tabular}{|c|c|c|c|c|c|c|c|c|}
\hline \multirow[t]{2}{*}{ Sporting Activities } & \multicolumn{2}{|c|}{$\begin{array}{c}\text { Total } \\
\text { Results }\end{array}$} & \multicolumn{2}{|c|}{ VCS } & \multicolumn{2}{|c|}{$\mathrm{CCC}$} & \multicolumn{2}{|c|}{ CCS } \\
\hline & $\mathbf{f}$ & $\%$ & $\mathbf{f}$ & $\%$ & $\mathbf{f}$ & $\%$ & $\mathbf{f}$ & $\%$ \\
\hline \multirow{2}{*}{$\begin{array}{l}\text { Outdoor Sports (like mountaineering, } \\
\text { rock climbing, trekking, fishing, } \\
\text { hunting) }\end{array}$} & & 27.3 & & 23.0 & & 34.0 & & 25.0 \\
\hline & 82 & 100.0 & 23 & 28.1 & 34 & 41.5 & 25 & 30.4 \\
\hline \multirow{2}{*}{$\begin{array}{l}\text { Team Sports (Like football, basketball, } \\
\text { volleyball) }\end{array}$} & & 26.7 & & 28.0 & & 23.0 & & 29.0 \\
\hline & 80 & 100 & 28 & 35.0 & 23 & 28.8 & 29 & 36.2 \\
\hline \multirow{2}{*}{$\begin{array}{l}\text { Water sports (Like swimming, sailing, } \\
\text { canoeing) }\end{array}$} & 42 & 14.0 & 17 & 17.0 & 14 & 14.0 & 11 & 11.0 \\
\hline & 42 & 100.0 & 17 & 40.5 & 14 & 33.3 & 11 & 26.2 \\
\hline \multirow{2}{*}{$\begin{array}{l}\text { Fitness (Like fitness, step aerobics, } \\
\text { pilates) }\end{array}$} & 35 & 11.7 & 0 & 9.0 & 17 & 17.0 & 0 & 9.0 \\
\hline & 35 & 100.0 & 9 & 25.7 & 17 & 48.6 & 9 & 25.7 \\
\hline \multirow{2}{*}{$\begin{array}{l}\text { Leisure sport activities conducted in an } \\
\text { urban park }\end{array}$} & 27 & 9.0 & 4 & 4.0 & 11 & 11.0 & 12 & 12.0 \\
\hline & 21 & 100.0 & 4 & 14.8 & 11 & 40.7 & 12 & 44.5 \\
\hline \multirow{2}{*}{ Folk dance and modern dance } & 11 & 3.7 & 0 & 0.0 & 8 & 8.0 & 3 & 3.0 \\
\hline & 11 & 100 & 0 & 0.0 & 8 & 72.7 & 3 & 27.3 \\
\hline \multirow{2}{*}{$\begin{array}{l}\text { Individual Sports (Like archery, } \\
\text { athletics) }\end{array}$} & 9 & 3.0 & 0 & 0.0 & 7 & 7.0 & 2 & 2.0 \\
\hline & 9 & 100 & 0 & 0.0 & 1 & 77.8 & 2 & 22.2 \\
\hline \multirow{2}{*}{$\begin{array}{l}\text { Motor Sports (Like motocross, off } \\
\text { road) }\end{array}$} & 8 & 2.7 & 2 & 2.0 & 5 & 5.0 & 1 & 1.0 \\
\hline & 8 & 100.0 & 2 & 25.0 & 5 & 62.5 & 1 & 12.5 \\
\hline \multirow{2}{*}{$\begin{array}{l}\text { Martial Arts (Like wrestling, karate, } \\
\text { taekwondo) }\end{array}$} & 8 & 2.7 & 4 & 4.0 & 3 & 3.0 & 1 & 1.0 \\
\hline & 0 & 100.0 & 4 & 50.0 & 3 & 37.5 & 1 & 12.5 \\
\hline \multirow{2}{*}{ Racket sports (Like tennis, badminton) } & 8 & 2.7 & 0 & 0.0 & 6 & 6.0 & 2 & 2.0 \\
\hline & 8 & 100.0 & 0 & 0.0 & 0 & 75.0 & 2 & 25.0 \\
\hline \multirow{2}{*}{$\begin{array}{l}\text { Air Sports (Like sky diving, para- } \\
\text { gliding, cliff diving) }\end{array}$} & 6 & 2.0 & 1 & 1.0 & 4 & 4.0 & 1 & 1.0 \\
\hline & & 100 & & 16.7 & & 66.7 & 1 & 16.7 \\
\hline
\end{tabular}

The reasons for going to the café/coffee shop and the LS level of participants are given in Table-5. As recorded in the table, the five significant reasons which have priority in all participants' reasons for going to the café/coffee shop were: "to be with my friends in my social life", "to have a fun time", "to play something with friends", "to eat/drink something with friends", and "going to the café/coffee shop makes me happy".

Table 5. The motivational reasons for going to the café/coffee shop and comparision by café types

\begin{tabular}{|c|c|c|c|c|c|}
\hline $\begin{array}{l}\text { The motivational reasons for going to } \\
\text { Café/Coffee Shop }\end{array}$ & VCS & $\mathrm{CCC}$ & CCS & $\begin{array}{c}\text { Total } \\
\text { Results }\end{array}$ & $\mathbf{F}$ \\
\hline $\begin{array}{l}\text { F01=To be with my friends in my social } \\
\text { life }\end{array}$ & $4.36 \pm 1.12$ & $3.63 \pm 1.26$ & $4.30 \pm 0.73$ & $4.10 \pm 1.11$ & 14.632 \\
\hline F02=To have fun time & $4.50 \pm 1.03$ & $3.62 \pm 1.15$ & $4.14 \pm 0.82$ & $4.09 \pm 1.07$ & 19.211* \\
\hline $\mathrm{F} 03=\mathrm{To} \mathrm{pl}$ & & 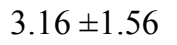 & $4.17 \pm 1.18$ & $3.96=$ & $30.902 *$ \\
\hline F04=To & $3.69=$ & 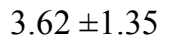 & $4.17 \pm$ & $3.83 \pm 1.39$ & 4.779* \\
\hline $\begin{array}{l}\text { F05=Going to café/coffee shop makes me } \\
\text { happy }\end{array}$ & 3. & 3.21 & $3.77=$ & $3.58 \pm 1.27$ & 6.594* \\
\hline $\begin{array}{l}\text { F06=To be away from daily life for a little } \\
\text { while }\end{array}$ & $3.70 \pm 1.53$ & $3.52 \pm 1.33$ & $3.19 \pm 1.23$ & $3.47 \pm 1.38$ & $3.578^{*}$ \\
\hline $\begin{array}{l}\text { F07 }=\text { To add value and meaning to } \mathrm{my} \\
\text { daily life }\end{array}$ & 3 & 1 & 4 & .26 & 44 \\
\hline $\begin{aligned} \text { F08 }=\text { To get rid of the problems of daily } \\
\text { life and responsibility }\end{aligned}$ & $3.49 \pm 1.49$ & $3.28 \pm 1.37$ & $3.38 \pm 1.12$ & $3.38 \pm 1.33$ & 0.620 \\
\hline F09=To mentally rest & 3.66 & 3.2 & 3.20 & $3.36 \pm 1.39$ & $3.616 *$ \\
\hline F10=To be with my work/school friends & 3.25 & $3.52 \pm 1.32$ & $3.09 \pm 1.42$ & $3.29 \pm 1.49$ & 2.145 \\
\hline $\begin{array}{l}\text { F11= There is no alternative place to be or to } \\
\text { go to in my neighborhood }\end{array}$ & $4.41 \pm 1.16$ & $2.37 \pm 1.32$ & $2.85 \pm 1.37$ & $3.21 \pm 1.55$ & $68.360 *$ \\
\hline F12 $=$ To socialize & $3.12 \pm 1.5$ & $04 \pm 1.40$ & $3.37 \pm 1.15$ & $3.18 \pm 1.39$ & 1.550 \\
\hline
\end{tabular}


F13=For watching football / basketball / volleyball events

F14=To belong to a group of friends

F15=To meet and talk to new and foreign people

F16=To use my free time efficiently

F17=Going to café/coffee shop is my favor

F18=To get rid of loneliness

F19=To be away from work/school for a little while

F20=To add/open a new dimension to my life

F21=To be away from scuttlebutt and backbiting for a little while

F22=To talk over the daily political subjects

F23=To increase my importance/visibility

F24=To add and create cultural value

F25=To help others and friends

F26=To be away from the family for a little while

F27=I thought that going to café/coffee shop and/or being there gives me social status

F28=To be away from the people around me for a little while

F29=To use/improve my ability and to learn new skills

F30 $=$ To (create some possibilities to) find a new job

$\mathrm{F} 31=$ To be recognized and be appreciated by others

F32 $=$ To find a new partner (beloved)

* p<0.05 1: Strongly disagree,..., 5: Strongly Agree

The first five important reasons for VCS participants were "to play something with friends", "to have a fun time", "there is no alternative places to be or to go in my neighborhood", "to be with my friends in my social life", and "going to cafélcoffee shop makes me happy". When we look these reasons, the first one gave some idea that participants were willing to go there to play some game with their friends. The second, the fourth and the last reason support the first one and show they were going there to be with their friends, being in VCS makes them happy and they meet there with friends from their social life. But the third reason shows they had no other leisure possibilities and so they go to the VCS.

The first five important reasons for CCS participants were "to be with my friends in my social life", "to play something with friends", "to eat/drink something with friends", "to have fun", and "going to the café/coffee shop makes me happy". When we look at these reasons, it is possible to say that the CCS participants were going to the café to meet with their friends both for social life and to play/eat/drink something and going to the café makes them happy.

The first five important reasons for CCC participants were "to be with my friends in my social life", "to eat/drink something with friends", "to have fun time", "to be away from daily life for a little while", and "to be with my work/school friends". When we look these reasons, it is possible to say that the CCC participants were going to café to eat/drink something with their friend both from their social life and work/school, and when they were there they forget the negative effects of daily life. 
On the other hand, the reasons F22 to F32 do not have an important effect on the participant's preferences in going to the café/coffee shop. All participants meet in all kind cafés with their friends, they were not going there to find new friends or a partner. And they were happy and satisfied with friendship and family relations, because they do not want to be away from their friends and families.

When the type of participants and their reasons are compared, there were no statistically meaningful differences in the reasons where they strongly agree; F01, F07, F08, F10, F15, F16, F19, and F20 and with which they strongly disagree; F22, and F30. This means that, all participants are willing or unwilling to prefer the café/coffee shop. The other reasons have statistically meaningful differences according to the participant's type. This means that, the reason does not have the same effect upon all participants. For example, while the reason F09 "to mentally rest" was favored by VCS participants, the reason F14 "to belong to a group of friends" was favored by CCS participants. The individuals in the same village have a common past and culture and they were born in the same social group, but individuals living in an urban environment need to create their own social groups by using some demographic variables like origin, religion, hometown, district, domain etc. to support each individual in urban life. The reason F25 supports this conclusion. The CCS participants were going to to the café to meet and help others/friends.

The reasons listed in Table- 5 can be divided in to two groups consisting of the intrinsic and extrinsic motivators explained by the Self Determination Theory. The intrinsic reasons motivate the individual themselves and are listed in bold format and push the individual to adopt a certain behavior or to go somewhere. The extrinsic reasons motivate the individual for external reasons and pull the individual to adopt a certain behavior or to go somewhere. All reasons can be explained through the Activity Theory and the Need Theory which are the secondary needs. Some of them are the function of the activity itself such as: F01, F02, and F03, some of them were the result of activity such as: F05, F09, and F18. Many reasons can be explained through the Achievement Goal Theory like F01, F02, F03, F04, F05, and F06.

\section{Discussion}

The reasons which cause the participants to go to the VCS, the CCS, and the CCC were examined in this research. The results of this study are restricted to those participants living in Antalya in Turkey.

Atay (1985), Tezcan (1994), Yıldız (1996), Shirine (2007), Sankır (2010) and Ulusoy (2011) concluded that cafés and coffee houses were accepted as a communal place which brings neighborhoods together for socialization, talking over daily issues, the place for fun and entertainment for neighborhoods. All these conclusions support the importance of this study and overlap, confirming this study's results.

These three types of cafés have importance in, and are usually determinants in the individuals' recreational life. As in other places, these places have effects for many reasons to be there or to go there. Yağbasan and Ustakara (2008) found the same demographic results as this study of coffee shops and cafés. They concluded that while the young prefer the CCC, people over the age of 40 prefer coffee shops, while singles prefer cafés the married prefer coffee shops, while the students were about $36 \%$ in cafés, $7 \%$ in coffee shops in this study. It was $34 \%$ in cafés and $5.5 \%$ in coffee shops in Yağbasan and Ustakara's study. While the primary reasons for going to cafés was having fun, being/meeting with friends, playing some games in Yağbasan and Ustakara's study, these reasons are approximately the same in this study. They concluded that all participants prefered inactive leisure activities such as watching $\mathrm{TV}$, resting at home and family togetherness, the same reasons, found in the same sequence in 
this study. These results are the same in this study, even though the year and the sample were different.

Yildız (1996) studied the reasons causing participants to go to the coffee houses in Elazığ city center and examined the reasons in respect to the demographic variables. Yildiz (1996) founded that $67 \%$ of attendees were aged between 18-40 years, mostly men, going to the coffee house for meeting with friends, eating something and playing some games, $66 \%$ of participants had been educated at high school and university. All these results overlap with the results of this study.

The results of this study can be explained through motivational theories. Going to the CCC, the VCS, and the CCS have activities in two dimensions. The first activity is going to these places is the activity itself, the second activity is the activity conducted in these places. Both dimensions can be explained by the Self Determination Theory, the Achievement Goal Theory, and the Activity Theory (Levy 1979; Crandall 1980; Deci \& Ryan 1985; Pintrich 2000; İbrahim \& Cordes 2002; Engeström et al. 2003). While intrinsic motivational reasons push the individual to carry out some behavior or to join in a recreational activity, the extrinsic motivational reasons pull individual to carry out some behavior or to go somewhere. For going to the CCC, the VCS, and the CCS both the intrinsic and the extrinsic motivational reasons are necessary. There are always more than two reasons [while one has the major effect the other(s) has/have an ordered effect] determining the individuals' behavior. The individuals going to these places accept being integrated together in these places and the activity done there. These are the subjects of the Activity Theory and the Achievement Goal Theory. The desirable activities make individuals happy and the people do and repeat these activities, like going to these places and/or doing something in these places. Many people especially the individuals in the villages and the CCS participants believe that going to these places and/or doing something in these places addresses their needs, which is explained by Maslow's hierarchy of needs. When these needs are satisfied, people become happy.

As Tezcan (1994) and Yildiz (1996) concluded, the social life in villages in Turkey is usually effected by communal pressure. Men are forced to behave within communal limits, for example, men must go to the VCS, if someone wants to stay at home with his family, his close friends call him a "henpecked husband - Kllıblk in Turkish". This overlaps with what Levy (1979) concluded.

\section{Conclusions}

As a result of this study, it can be concluded that the participants living in the city have the possibility to go to cafés have a recreational advantage, and they spend more money and much more time on their recreational life than the others. While VCS and CCS participants were men, self-employed, working in the private sector, have a regular income and prefer passive recreational life, like watching TV, resting at home and family togetherness, CCC participants were males and females together, even if the percentages were not equal, were young, employed in the public and private sectors, students and they prefer active leisure activities like going to the cinema, going to the theatre, being interested in photography and music, outdoor activities etc. Cities present more recreational opportunities. The reasons for going to cafés were friendfocused, such as being with friends, eating/drinking/playing something with them. But in the village there was the lack of recreational alternatives and the men have to go the VCS, and they prefer inactive leisure.

When compared to other groups, the participants in the village spent much more time in the VCS on week days, the CCC participants were younger and spent much more money in cafés in a week, and the CCS participants spent more time in CCS at the weekend. None of the 
participants read books or go to the cinema regularly. It can be concluded that our society has poor reading habits. While VCS and CCS participants spent more than 24 hours a week watching TV, the others spend half of this time.

\section{Recommendations}

All central, local authorities and nongovernmental organizations must take responsibility in enriching the leisure life in villages. Some courses, workshops and some active demonstrations such as cinema, theatre, concert and etc. must be organized and all villages must be informed about the active life and leisure and be pushed towards a positive life. If they have some possibilities like active reading, active recreational sport/art/culture life, such as trekking, hiking group fitness, village theatre, folk dance festival etc. their life will be effectively changed.

The CCS participants efforts to urbanize, to open windows to urban life should be supported by all central, local authorities and nongovernmental organizations. Some recreational projects can be undertaken to change the individual's life. 


\section{REFERENCES}

Aktaş G. G. (2011). "Public Life in Anatolia and Its Spatial Impresses". Gazi Üniversitesi Güzel Sanatlar Fakültesi, GSF Sanat ve Tasartm Dergisi 7 (2011) 55-68.

Atay M. (1985). Keban Barajı Nedeniyle Elazığ'ın 1800 Evler Mahallesi'ne Göç Edenlerin Kentlileşme Sorunları. Yayımlanmamış Doktora Tezi. Fırat Üniversitesi. Elazı 1985.

Bingül İ. (2004). "Kahvehane ve Eğlence”. Toplumsal Tarih 126 (2004) 70-72.

Crandall R. (1980). "Motivation for Leisure". Journal of Leisure Research 12/1 (1980) 45-54.

Deci E. L. \& Ryan R. M. (1985). "The General Causality Orientations Scale: Self Determination in Personality". Journal of Research in Personality 19 (1985) 109-134.

Duben A. (2001). Bir Beyoğlu Fotoromanı 1870 Beyoğlu 2000. Ed. Münevver Eminoğlu. İstanbul 2001.

Durukan L. (2013). “Çekirdek'ten Kültür'e: Türk Kültüründe Kahve ve Kahvehane”. Bilim ve KültürUluslararası Kültür Araştırmaları Dergisi 2 (2013) 127-138.

Evren B. (1996). Eski İstanbul'da Kahvehaneler. İstanbul 1996.

Engeström Y., Miettinen R. \& Punamaki R. L. $\left(2003^{2}\right)$. Perspective on Activity Theory. New York 2003.

Hamadeh S. (2007). The City's Pleasure: Istanbul in Eighteenth Century. Seatle, London 2007.

Hattox R. S. (1998). Kahve ve Kahvehaneler. Çev. Nurettin Elhüseyni. İstanbul 1998.

Heise U. (2001). Kahve ve Kahvehane. Çev. Mustafa Tüzel. Ankara 2001.

İbrahim H. \& Cordes K. A. $\left(2002^{2}\right)$. Outdoor Recreation, Enrichment for a Lifetime. Champaign, Il 2002.

Levy J. (1979). "Motivation for Leisure: An Intereactionist Approach". Eds. H. İbrahim \& R. Crandall. Leisure: A Psychological Approach (1979). Los Alamitos, CA.

Öztürk S. (2005). “Osmanlı İmparatorluğu'nda Kamusal Alanın Dinamikleri”. İletişim Dergisi 21 (2005) 95-124.

Özünlü E. E. (2010). "XVI. Yüzyıl Osmanlı Kentlerinin Ekonomik Nitelikleri Üzerine Bir Karşılaştırma Denemesi”. Kastamonu Eğitim Dergisi 18/1 (2010) 257-270.

Pintrich P. R. (2000). "An Achievement Goal Theory Perspective on Issues in Motivation Terminology, Theory and Research". Contemporary Educational Psychology 25 (2000) 92-104.

Sankır H. (2010). "Osmanlı İmparatorluğu'nda Kamusallığın Oluşumu Sürecinde Kahvehanelerin Rolü Üzerine Sosyolojik Bir Değerlendirme”. Hacettepe Üniversitesi Türkiyat Araştırmaları Dergisi 13 (2010) 185-210.

Shirine H. S. (2007). “18. Yüzyıl İstanbul'unda Kamusal Yaşam”. Osmanlı Bankası Arşsiv ve Araştırma Merkezi. Kaynak: http://www.obarsiv.com/e_voyvoda_guncel.html. Erişim Tarihi: 13 Temmuz 2015.

Tezcan M. (1994). Boş Zamanların Değerlendirilmesi Sosyolojisi. Ankara 1994.

Ulusoy K. (2011). "Türk Toplum Hayatında Yaşatılan Kahve ve Kahvehane Kültürü (Bir Sözlü Kültür ve Sosyal Çevre Eğitimi Çalışması)”. Milli Folklor Dergisi 23/89 (2011) 159-169.

Yağbasan M. \& Ustakara F. (2008). "Türk Toplumunda Kahvehane ve Kafelerdeki İletişimsel Ortamı Belirlemeye Yönelik Bir Alan Araştırması (Gaziantep İli Örneği)". Fırat Üniversitesi Sosyal Bilimler Dergisi 18/1 (2008) 233-260.

Yıldız C. M. (1996). "Kahvehanelerin Sosyal Hayattaki Yeri”. Kaynak: http://acikerisim.bingol.edu.tr: 8080/xmlui/bitstream/handle/11472/540/kahvehaneler.pdf?sequence=1. Erişim Tarihi: 20 Ocak 2015. 